УДК 070.19

\title{
ІДЕОЛОГІЯ, ГЕНДЕР, ДИСКУРС: НОВІ ПІДХОДИ ДО ВИВЧЕННЯ ІСТОРІЇ ПРЕСИ
}

\author{
Ольга Хамедова \\ Киїський університет імені Бориса Грінченка, \\ вул. Маршала Тимошенка, 13 Б, 04212, Киї, Україна, \\ e-mail: o.khamedova@kubg.edu.ua \\ https://orcid.org/0000-0002-9545-4464
}

У статті досліджуються медіадискурси західноукраїнської преси 1920-1930-х років крізь призму новітніх підходів - дискурс-аналітичного й гендерного. Доводиться, що медійний простір західноукраїнської преси був ареною боротьби за гегемонію двох ідеологічних дискурсів, патріархатного і феміністичного. Зафіксовано значний поступ у феміністичних прагненнях українок i, відповідно, те, що патріархатна ідеологія позбулася монопольного статусу у провідних західноукраїнських часописах міжвоєнного двадцятиріччя.

Ключові слова: дискурс, ідеологічний дискурс, дискурс-аналіз, ідентичність, гендер.

У сучасному українському журналістикознавстві відбуваються інтенсивні пошуки новітньої, адекватної викликам часу, методології, яка б враховувала взаємодію медіа та суспільства. Преса як соціальний інститут значною мірою впливає на сприйняття світу, визначає культурно-ціннісні орієнтири і світогляд людини. Е. Лакло і Ш. Муфф наголошували, що дискурс формує соціальний світ за допомогою значень [1, с. 26]. Н. Феркло взагалі визначав дискурс як «форму соціальної практики, яка і конституює соціальний світ, і конституюється в інших соціальних практиках» $[1$, c. 110$]$.

Дослідження історії преси передбачає врахування багатьох факторів: історичних, політичних, економічних реалій доби, соціокультурного контексту тощо. Тому зрозумілою стає зацікавленість науковців міждисциплінарними підходами, зокрема дискурс-аналізом, який вважається найбільш адекватним для дослідження медіадискурсів, оскільки дозволяє відповісти на наступні запитання: «яка саме форма репрезентації соціального світу домінує; які форми взаємодії формує медіа-текст між людьми і світом, а також між можновладцями та рештою; як одне й те саме значення може змінюватися залежно від того, в якому медіа-тексті воно використовується» [2, с. 13].

Дискурс-аналітики медіатекстів, зокрема Т. ван Дейк, Е. Лакло, Ш. Муфф, Н. Феркло, Д. Матісон, М. Тетерюк наголошували на необхідності вивчення ідентичностей як способів означення певної групи, а також дослідження їхньої представ-

(C) Хамедова О., 2019 
леності у боротьбі за «гегемонію» в ідеологічних дискурсах [1, с. 73]. Дослідники аналізували боротьбу ідеологій у суспільстві у контексті встановлення дискурсивної влади (М. Фуко) як влади загальновизнаних знань, правил, уявлень, установлених норм, із якими всі погоджуються і яких дотримуються [3, с. 32]. Ця влада-знання поширюється у тому числі і через пресу: «Медії мають повноваження створювати і поширювати дискурси - механізми облаштування невидимих влад [3, с. 33]. Виявити дискурсивні влади можливо через аналіз боротьби дискурсів, кожний з яких представляє певний ідеологічний погляд на світ: «ключове поняття цієї теорії - боротьба дискурсів. Різні дискурси - кожний з яких презентує певний спосіб спілкування i розуміння соціального світу - знаходяться у постійній боротьбі за зверхність. Вони намагаються зафіксувати своє значення у мові. Тоді вищість можна розуміти як домінування однієї точки зору» $[1, \mathrm{c.26}]$.

Подібне загострення конфлікту ідеологічних дискурсів відбувалося у першій третині XX століття у Західній Україні. Трагічні події першої світової війни, глобальні політичні трансформації у Європі, боротьба за незалежність України 1917-1921 років, утворення ЗУНР і проголошення соборності України, поразка українських національно-визвольних змагань та анексія західноукраїнських земель Польщею, Румунією і Чехословаччиною - цей суспільно-політичний досвід вплинув на світогляд і громадянську свідомість західноукраїнської спільноти у міжвоєнне двадцятиріччя. Крім того, у Галичині і Буковині потужними були патріархальні традиції часів Австро-Угорської імперії, але водночас відчувалися імпульси європейського жіночого руху. Достатньо згадати, що у Галичині і Волині діяв Союз українок, одна 3 найчисельніших жіночих організацій не тільки в Україні, але і в Свропі (за різними оцінками нараховував від 45000 до 100000 учасниць). У Буковині діяла не така масова, проте популярна «Жіноча громада», а у Закарпатті - «Жіночий Союз» і розгалужена система філій жіночих гуртків при культурно-освітньому товаристві «Просвіта». Тому, на нашу думку, дискурс-аналітичний підхід варто поєднати зі здобутками феміністичного критицизму, який сфокусований на «дискурсних репрезентаціях гендеру, стратегіях формування рольових ідентифікацій» [4, с. 17].

Мета нашої статті - дослідити соціальний феномен пробудження емансипаційних прагнень українок та висвітлення його у західноукраїнській пресі 1920-1930-х років за допомогою дискурс-аналітичного та гендерного підходів. Об’єктом аналізу є популярні громадсько-політичні та універсальні (класифікація Л. Сніцарук [5, с.22]) українськомовні часописи («Діло», «Час», «Новий Час», «Свобода»), які видавалися легально на західноукраїнських землях у міжвоєнний період.

Для дискурс-аналітика важливо, що «фактично було сказано чи написано, досліджуючи патерни висловлювань та визначаючи соціальні наслідки певних репрезентацій реальності» [1, с. 49]. Відзначимо, що дискурс-аналіз не $є$ нейтральною науковою методологією, за його допомогою дослідники намагаються змінити соціальне середовище. «Під прапорами свободи» критичний дискурс-аналіз приймає сторону дискримінованих соціальних груп» [1, c.114], а такими є українські жінки як субординована група у міжвоєнний період за національною і гендерною ознакою. Дискурс формується «завдяки частковій фіксації значень навколо деяких вузлових точок» $[1$, c.57]. Таким чином, «жінка» як «вузлова точка» $є$ об'єктом боротьби за значення між конкурентними ідеологічними дискурсами. Залежно від того, яким значенням журналіст наповнює iï, актуалізується певний дискурс. 
«Час», щоденна українська газета Буковини, позиціонувала себе як незалежна і підтримувала державницький вектор українства. В умовах румунської окупації та постійного тиску і переслідувань румунської влади, щоденник «Час» швидко став найпопулярнішим серед українців буковинського краю і поза ним. 3-поміж інших буковинських газет, «Час» виділявся тим, що мав рубрики «Жіночі Вісти» і «Жіноче Діло», в яких повідомляли про діяльність жіночих організацій, розповідали про видатних українок.

Буковинські журналісти розмірковували про суспільні трансформації, пов’язані з інститутом сім'ї, зокрема про це йшлося у статті «Родина» [6, с.2]. Консервативну буковинську громаду лякали всі суспільні новації у сфері родини: укладання шлюбу без втручання церкви, концепція шлюбу як союзу рівноправних партнерів, можливість розлучення. Автор процитував поширені стереотипи («Родина, підстава нації, хитається... Змінилися часи, почуємо «Це вже послідня тисяча», та тим подібне» $[6$, c. 2]). Він намагався вплинути на громадську думку і стверджував, що відмирання старого патріархального устрою і народження нової сім'ї - на краще: «Зрівнялися сьогодні люди, муж та жена - це рівні товариші, чи приятелі, чи як там вже хочете, котрі зв'язуються на те, щоб вести спільне життя вже за певних природних, соціальних та инших причин» [6, с. 2].

Журналісти цієї газети постійно інформували про культурно-просвітницьку діяльність буковинської жіночої організації «Жіноча громада», яка працювала у Чернівцях з 1906 року. Поступово формувався образ нової буковинської жінки, яка вже була помітною у громадському і культурному житті регіону.

Закарпатські журналісти також намагалися залучити жіноцтво до активної громадської роботи. Так, у статті-відозві «Нас жде нарід» [7, с. 2] Ю.Грім закликав патріотів краю, розвивати мережу «Просвіти», а також «Січі», «Пласту», «Лугу», які виховували молодь у національному дусі. Автор намагався залучити і жіноцтво до активної участі у громадському і культурному житті: «Закладайте жіночі гуртки при «Січі», закладайте філії «Жіночого союза»!» [7, с. 2]. Таким чином, автор конструював національну модель соціально паритетних стосунків жінки і чоловіка зі спільною відповідальністю за українське відродження Закарпаття. Проте доводиться визнати, що у порівнянні з галицькою і буковинською пресою, закарпатська міжвоєнного періоду жінкам присвячувала обмаль матеріалів.

Львівський щоденник «Діло» був одним із найпопулярніших серед українців міжвоєнного покоління. Ю.Шаповал, дослідник історії часопису «Діло», наголошував на тому, що газета закликала до формування патріотичної ідеології, яка б об’єднала українців задля спільної боротьби на політичному фронті $[8$, с.236]. Один із небагатьох, часопис «Діло» висвітлював проблему емансипації жіноцтва, мав тематичну сторінку «Жіночий Вістник». Дописувачками цієї сторінки були активні учасниці жіночого руху, переважно діячки Союзу українок, які вважали своїм обов’язком піднесення національної і громадянської свідомості жіноцтва. За умови відсутності власного пресового органу аж до 1935 року, «Діло» стало тією дружньою медійною платформою, яка дозволяла Союзу українок формувати власний публічний дискурс. Тексти учасниць цієї організації були жанрово різноманітними: публіцистичні статті, замітки, відозви, огляди, нариси, рецензії, тощо. Редагувала цю сторінку активістка та багаторічна лідерка Союзу українок, Мілена Рудницька, про що свідчить 
редакційне повідомлення: «Всі матеріали, призначені до «Жіночого Вістника» просимо надсилати на адресу: Мілена Рудницька-Лисяк, Львів, Тарновського, 7» [9, с. 7].

Одним зі своїх завдань дописувачки вважали заохочення українок до праці поза межами родини, задля цього читачок постійно інформували про досягнення жіноцтва у професійній сфері в інших країнах. У рубриці «3 міжнародного жіночого руху» [9, с. 6] було вміщено повідомлення про те, що у Британії прийнято закон «про службу жіноцтва в характері полісменів (поліцаїв). 20 перших жінок полісмен має стати зав'язком майбутньої жіночої поліції» [9, с. 6]. Проте гендерні стереотипи спрацьовували і у такому прогресивному законі. Жінка, на думку законодавців, не могла виконувати роботу чоловіка-поліціянта, ii треба було наділити окремими «жіночими» обов'язками: «арештування жінок, переслухування свідків із жінок і дітей, стеження за вуличними дівчатами» [9, с. 6].] Звичайно, сама по собі публікація руйнувала поширений гендерний стереотип. Для адекватного дискурс-аналізу «дослідник має визначити те, які твердження сприймаються як істинні чи «природні», а які ні» [1, с. 49]. Авторка хотіла виховати у галицької публіки переконання про необхідність докорінного перегляду традиційного гендерного розподілу на ринку праці, і наголосила на тому, що соціальний статус жінки кардинально змінився у Європі.

Про досягнення жіноцтва у світі, зокрема у професійній сфері, повідомляла також буковинська газета «Час». Наприклад, у рубриці «Новини» у замітці «Жінки кращими купцями» інформувалося про перших жінок, які рекламували автівки на міжнародній виставці у Лондоні. Автор відзначив високі професійні якості автодилерок, їхнє знання психології потенційних покупців: «жінки у ролі купців вміли краще похвалити товар, підійти під смак своєї клієнтелі, ніж мущини» [10, с. 4].

Очевидно, що тогочасних чоловіків лякали такі стрімкі суспільні трансформаціï, тому у багатьох публікаціях цей страх і внутрішній спротив виявлялися передусім в авторській інтенціональності: нотках роздратування, незадоволення, іронії. Галицькі і буковинські жінки 1930-х років сміливо експериментували із зовнішністю і намагалися відповідати модним стандартам епохи. Натомість чоловіки неоднозначно сприймали зміни у жіночій моді та уявленнях про красу, свідченням чого $\epsilon$ стаття анонімного автора «Жінка, волосся і вчені», уміщена у буковинському часописі «Час» [11, с.2]. Журналіст висловив занепокоєння тією модною тенденцією, що жінки відрізають коси і роблять короткі зачіски. Він звернувся до псевдонаукових доказів вчених: «тепер знайшовся ще більший ворог короткого волосся, Бруно Етикінг, професор антропольогії на університеті Колюмбія в Ню-Йорку, котрий заявляє, що жінки одного дня не зчуються, як побачать на грудях, руках і ногах густий волос, як у мавпи. I коли будуть кроїти волосся регулярно, то будуть присилувані голитися денно» [11, с. 2]. Дискурс-аналітики стверджують, що, окрім вивчення семантики тексту, його структури, стилістичних форм, важливими є імпліцитні, приховані смисли, які також виявляють ідеологічний вплив на читачів [12]. Тому виникає питання про те, чому автор приділяє стільки уваги жіночій зачісці. Довге волосся $є$ поширеним гендерним маркером жіночності. Дискурсивна влада здійснює гендерне дисциплінування тіл через низку норм, приписів і заборон. Одна з дисциплінарних практик - плекання відмінностей у зовнішності чоловіків і жінок, зокрема через зачіску. Відхід від цієї традиції автор сприймає як ознаку деградації сучасного суспільства і наводить аргументи тих, хто підтримує традиційний образ жінки: «одні через консервативний дух, бо «бабці і мами носили довгий волос», другі кажуть, що 
короткий волос робить жінку брутальною. Инші - що робить жінку менш інтелігентною - короткий волос, короткий розум» [11, с.2].

Журналіст апелював також і до фольклорної традиції, втіленої у народних прислів’ях і приказках. Приказка, якою він завершив цю думку, дуже показова: «з бабами і чорт ради собі не може дати», за нею приховано страх ще більшої соціалізації жінки [11, с. 2]. Прикметною є тональність, в якій написано статтю: жартівливій, подекуди іронічній. Грайливо-повчальний тон $є$ виявом зверхнього і зневажливого ставлення до жінки, іiі «інфантилізації», яка призводить до знецінення досягнень жіноцтва [3, с.114]. Таким чином автор намагався відновити патріархатні норми як законні та єдино можливі у медійному дискурсі.

До текстів, сповнених гендерних упереджень і стереотипів, контрастували матеріали активних діячок Союзу українок (М. Рудницька, К. Малицька, М. Струтинська та ін.), які публікувалися у часописі «Діло», а звідти їх передруковував і буковинський «Час». Своєрідним маніфестом українського фемінізму стала аналітична розвідка М. Рудницької «Новий тип жінки» [13, с.12] про розуміння фемінності і маскулінності у тогочасному українському суспільстві. Вона стверджувала, що завдяки розвитку жіночого руху, «цього наймогутнійшого визвольного руху в історії людства», відбувається формування модерної жінки [13, с. 12]. На думку авторки, саме жіночий рух вивів жінку поза межі родинного світу і зробив рівноправною учасницею політичного та економічного життя. Ця нова роль призвела як до суспільних змін, так змінила і психологію самої жінки. Авторка перераховує риси нової модерної жінки: самостійність, активність, раціональність, «проблєматизм» (внутрішня конфліктність), право на власний вибір, відповідальність за своє життя. Аналіз авторки грунтується на «порівнянні »давньої» (традиційної, патріархальної) жінки і модерної. Давня жінка була сентиментальною і пасивною, бо «творення держави, законів, науки, релігії, моральних норм - залишала мужчині» [13, с. 12], причиною цьому була громадська думка, яка засуджувала активність жінки як «гріх супроти ідеалу жіночости» [13, с.12]. Натомість модерна - раціоналістка та волюнтаристка не залежить від чоловіка і вміє сама заробляти. На думку авторки, матеріальна незалежність породжує повагу до себе і змінює усвідомлення своєї ролі у сім'ї: «коли сама є щасливою, зможе виповнити свої обов'язки дочки, жінки, матері» [13, с. 12 ].

М. Рудницька проаналізувала сучасне становище жіноцтва у світі і Україні і визначила основні проблеми (актуальні й у наш час), з якими жінки стикаються: «як розв'язати конфлікт між змаганням до повного індивідуального життя людини і материнством й як погодити обов'язки матері і хазяйки, з одного боку, з обов'язками позадомашнього звання, зі своїми особистими аспіраціями до знаття?.. Як творити нові вартости в царині матеріяльної чи духової культури, не зрікаючись рівночасно й особистого щастя? Як бути заєдно людиною і жінкою?» [13, c.12]. М. Рудницька не обмежилася лише глибоким аналізом того, як поступово у суспільстві еволюціонувало уявлення про жіночність. Вона визначила і характерні риси нового маскулінного типу. Новий чоловік - інтелектуальний і водночас чутливий, не потребує вже традиційної наївної жінки - напівдитини зі «здивованими очима і з малими безпомочними руками» $[13$, с.12]. Він хоче бачити поруч товаришку, яка б була діяльною у громадському житті.

Блискучим зразком феміністичної критики є рецензія іншої активістки Союзу українок, Марії Струтинської, на книгу французького письменника Поля Маргерітта 
«Adame Eve et Bridoison», яку було уміщено на тематичній сторінці «Жіночий Вістник» щоденника «Діло» [14, с.6]. Рецензентка визначила жанр книги як «суспільна студія на жіноче питання» [14, с.6]. Ї̈̈ зацікавило те, що феміністичну книжку написав чоловік, до того ж - націоналіст, «що признає лише один імператив: добро Батьківщини» [14, с.6]. Такий ідеологічний симбіоз - поєднання фемінізму і націоналізму - неодноразово ставав приводом для дискусій серед діячок Союзу українок. Авторці імпонувало, що французький дослідник змагається за рівноправність жінки. У книзі відзначалися кардинальні зміни суспільного статусу жіноцтва після Першої світової війни внаслідок їхнього масового виходу на ринок праці. Жінки вибороли право професійної реалізації, працюючи замість чоловіків під час війни.

Рецензентка не замовчувала й іншу порушену автором проблему, а саме - сексуальний досвід жінки під час війни. Українські жінки, наприклад, про свій «інтимний травматичний досвід» під час війни могли розповідати лише в особистих щоденниках, спогадах і приватному листуванні [15, с.99]. Рецензентка сміливо виводить 3 приватного дискурсу Галичини табуйовану тему і вказує на іï складові: «випадкові любови, непредвиджувані материнства, безпощадне опущення» $[14$, с.6]. Вона погодилася з автором, що «всі ці найріжнорідніші обставини, які витворювала війна, приспішили сексуальну еволюцію жінки» [14, с.6]. М. Струтинська підтримала автора в тому, що стосувалося сексуальної свободи («права на любов») незаміжніх жінок, кількість яких значно зросла після війни. Це була одна з перших публічних артикуляцій жіночого трагічного досвіду війни та його наслідків, актуальний для України так само, як і для Франції.

Рецензентка позитивно оцінила те, що французький письменник звернув увагу на інтимний аспект життя заміжніх жінок, адже він не побоявся висвітлити в іншому ключі сакральну, освячену церквою, тему материнства. Автор делікатно висловився про репродуктивні права жінок: необхідність контролю народжуваності і запобігання небажаної вагітності. М.Струтинська доводила, що зміни статусу жінки у родині допоможуть змінитися всьому суспільству, адже «жити, значить змінятися» $[9$, с. 6]. Артикулюючи подібні теми, вона дискутувала з порядком патріархатного дискурсу, і деконструювала його «ідеологічні ефекти» [1, с.112 ].

Активна учасниця Союзу українок акцентувала увагу читачів на тих епізодах книги французького письменника, які були суголосні проблемам українського жіноцтва і могли були корисними для розвитку жіночого руху в Україні. Провідна думка книги імпонувала українським феміністкам: «нова, освічена, повноправна жінка - основою нової держави» [14, с.7]. Активістки Союзу українок, зокрема і Марія Струтинська, пов’язували свої емансипаційні прагнення з національними, і вірили, що незалежна Батьківщина автоматично наділить жінку усіма правами.

Таким чином, дискурс-аналіз преси виявив ідеологічну конкуренцію і протиборство феміністичного і патріархатного дискурсів, які точилися на шпальтах популярних західноукраїнських часописів міжвоєнного періоду. I хоча «жіноча тема» залишалася периферійною, зафіксовано значний поступ у феміністичних прагненнях українок i, відповідно, те, що патріархатна ідеологія позбулася монопольного статусу у національно-демократичній пресі.

Ослаблення і руйнація патріархального канону відбувалася за рахунок публікацій, які були присвячені новій соціальній ролі жінки. Журналісти-чоловіки, попри значний інтерес до теми емансипації жінки, не могли позбутися власних патріар- 
хальних стереотипів та упереджень, що виявлялося у формі окремих гендерно маркованих коментарів чи емоційних оцінок, їхні публікації відзначалися авторською інтенціональністю, суб'єктивним фокусуванням інформації. Крім того, до медійних наративних засобів, за допомогою яких моделювалися жіночі образи в популярних західноукраїнських часописах міжвоєнного двадцятиліття, належать: звернення до історії, зокрема життєпису видатних українок; фреймування; стереотипізація; застереження, докори, погрози на адресу порушниць гендерної норми; апеляція до авторитетних думок або ж громадської думки, які підтримували гендерний режим. Натомість жінки намагалися стати «видимими» для читацької публіки, заявляючи про себе як про авторок гендерно чутливих публікацій і формуючи таким чином дискурс, опозиційний до патріархатного. Якщо ж оцінювати цілісно, то публікації популярних західноукраїнських часописів («Діло», «Час», «Новий Час», «Свобода») - свідчення неминучих, хоча й повільних змін громадської думки західноукраїнського суспільства щодо соціальної ролі жінок і чоловіків.

Подальше дослідження медіатекстів за допомогою дискурс-аналізу, зокрема в аспекті взаємодії медіа та суспільства, медіа та культури, вважаємо плідним та перспективним напрямком журналістикознавства.

\section{REFERENCES}

1. Филлипс Л. Йоргенсен М. В. Дискурс-анализ. Теория и метод. Харьков: Изд-во «Гуманитарный центр», 2008. 352 с.

2. Матисон Д. Медиа-дискурс. Анализ медиа-текстов. Исследования медиа и культуры. Харьков: Изд-во «Гуманитарный Центр», 2017. 264 с.

3. Гендер для медій. Підручник із гендерної теорії для журналістики та інших соціогуманітарних спеціальностей / За ред. М. Маєрчик, О. Плахотнік, Г. Ярманової. К.: Критика, 2014. 217 с.

4. Павлюк Л. С. Риторика, ідеологія, персуазивна комунікація. Львів: ПАІС, 2007. $130 \mathrm{c}$.

5. Сніцарчук Л. Українська преса Галичини (1919-1939): політико-правові умови функціонування, тенденції розвитку, організаційно-журналістська практика. Автореф. дис. на здобуття наук. ступеня доктора наук із соціальних комунікацій. К., 2010. $25 \mathrm{c}$

6. Час. 1934. 9 березня. Ч. 1553. С. 2.

7. Грім Ю. Нас жде нарід // Свобода. 1929. 7 листопада. Ч. 45. С. 2.

8. Шаповал Ю. «Діло» (1880-1939 рр.): Поступ української суспільної думки. Львів, 1999. $383 \mathrm{c}$.

9. Діло. 1922. 30 вересня. Ч. 23. С. 7.

10. Час. 1933. 17 лютого. С. 4.

11. Час. 1933. 4 лютого. С. 2.

12. Шевченко А. Ю. Дискурс-анализ политических медиа-текстов. Полис. Политические исследования. 2002. № 6. С.18-23 [Електронний ресурс]. Режим доступу: https://http://www.politstudies.ru/files/File/2002/6/Polis-2002-6-Shevchenko.pdf

13. Рудницька М. Новий тип жінки // Діло. 1924. 27 квітня. Ч. 93. С. 12.

14. Струтинська М. Книжка доброї віри // Діло. 1922. 30 вересня. Ч. 23. С. 6-7. 
15. Байдак М., Бежук О. Українське жіноцтво в роки Першої світової війни: спектр суспільних ролей // Українські жінки у горнилі модернізації / Під заг. ред. О. Кісь. Харків: Книжковий Клуб «Клуб сімейного дозвілля», 2017. С. 78-106.

\title{
IDEOLOGY, GENDER, DISCOURSE: NEW APPROACHES TO THE STUDY OF PRESS HISTORY
}

\author{
Olha Khamedova \\ Borys Grinchenko Kyiv University \\ 18/2 Bulvarno-Kudriavska Str, 04053, Kyiv, Ukraine \\ e-mail: o.khamedova@kubg.edu.ua \\ https://orcid.org/0000-0002-9545-4464
}

The paper deals with the actual problem of Ukrainian journalism - the search for a new methodology that is adequate to the challenges of the time, taking into account the interaction between media and society. The issue of the correlation of national and gender identities was relevant in the Western Ukrainian society of the interwar period.

The problem of the interaction of gender and national identities should be analyzed as a question of colonialism, nation and gender in the context of the Ukrainian history of the 1920s-1930s. In addition, the national discourse with its ideology of devoted service to the people and state-building intentions was a decisive factor for the interwar generation in the conditions of the occupation of Ukraine.

The most adequate scientific method of studying this problem is the discourse analysis. Discourse analysis studies identity as a means of defining a particular group, as well as the representation of this group in the struggle for hegemony in ideological discourses. Therefore, study the Western Ukrainian press of the 1920s-1930s (for example, the popular Galician, Bukovinian and Transcarpathian periodicals) through the prism of modern approaches discourse analysis and gender analysis - is proposed in the paper. The discourse representations of femininity are explored in the ideological context of the national-democratic press. It turns out that the media space of the Western Ukrainian press was the scene of the struggle for the hegemony of two ideological discourses, patriarchal and feminist. Feminist discourse is represented by publications by the members of the Union of Ukrainian Women on the pages of popular periodicals. In these publications, the «taboo» issues of feminine identity were articulated, which was perceived as a threat to traditions and violations of public order, since authors thus redefined the social world. Significant progress has been made in the feminist aspirations of Ukrainian women and, accordingly, the fact that patriarchal ideology lost its monopoly status in the national-democratic press.

Key words: discourse, ideological discourse, discourse analysis, identity, gender. 